\title{
Implementing International Environmental Treaties in Developing Countries: China's Compliance with the Montreal Protocol
}

Jimin Zhao*

It has been widely recognized that environmental protection is a global issue and developing countries are making increasingly significant contributions to global environmental problems. Studies show that the most adverse effects of climate change are likely to appear in developing countries and global emissions of greenhouse gases are unlikely to be controlled without their participation. ${ }^{1}$ However, developing countries that lack technology and resources may demand assistance from developed countries to deal with global environmental problems. Success in protecting the global environment thus depends crucially on the ability of international institutions to design effective international environmental agreements (IEAs) to engage developing countries. ${ }^{2}$ But to do so effectively requires better understanding of how developing countries comply with international environmental treaties. To date, there has been little research on this topic.

China must play a major role in solving global environmental problems because of its size and surging economic growth. After the United States, China is the second largest emitter of greenhouse gases that cause climate change, and China is the world's largest producer and consumer of substances that damage the ozone layer. Due to continuous rapid economic growth and the tremendous rise in the demand for automobiles in China, the International Energy Agency predicts that the increase in greenhouse gas emissions in China alone for the 2000 to 2030 period will nearly equal that of all other countries in the world combined. ${ }^{3}$

As the most successful IEA to date, the Montreal Protocol on Substances That Deplete the Ozone Layer (hereafter referred to as "the Montreal Protocol" or "the Protocol") has involved an exceptionally large number of developing countries.

* I am grateful to three anonymous reviewers for their helpful comments on a draft of this article.

1. IPCC 2002; and Blanchard et al. 2003, 280-303.

2. Keohane, Haas, and Levy 1993, 6; and Batabyal 1998.

3. The New York Times, 22 October 2003.

Global Environmental Politics 5:1, February 2005

๑ 2005 by the Massachusetts Institute of Technology 
As of July 2003, 130 of the 183 parties to the Protocol were developing countries. ${ }^{4}$ The Montreal Protocol stipulates control measures and schedules for countries to phase out production and consumption of chemicals that destroy the ozone layer. These chemicals, called ozone-depleting substances (ODS), include chlorofluorocarbons (CFCs), which are used in the production of refrigerators, foams, mobile air conditioning, aerosol sprays, and tobacco; halons, which are used in fire fighting; ${ }^{5}$ carbon tetrachloride (CTC) and methyl chloroform, which are used as solvents in engineering and manufacturing operations; and methyl bromide, which are used in agricultural pesticides and tobacco production. The year 2010 is the deadline for signatory developing countries to completely phase out the use and production of CFCs and halons. The Montreal Protocol also has some unique features, in particular the establishment of the Multilateral Fund (MLF) to provide financial assistance to developing countries. Revisions to the 1987 Montreal Protocol were made in London (1990), Copenhagen (1992), Vienna (1995), Montreal (1997), and Beijing (1999).

China ratified the London Amendments to the Montreal Protocol in 1991 and the Copenhagen Amendments in 2003. China has been the world's leading consumer and producer of ODS since 1996. Developed countries that had previously been the major ODS producers and consumers phased out major halons in 1994 and CFCs in 1996. Meanwhile, during its "grace period" under the Protocol, China's demand for ODS increased due to rapid economic growth. Most ODS targeted by the Protocol are produced and consumed in China, with CFC 11, CFC 12, and halon 1211 being the most prevalent.

China thus far has signed more than 20 international environmental treaties. ${ }^{6}$ However, the extent to which it has complied with these IEAs and the factors that have affected its compliance have not been investigated systematically. In this article, I try to fill in this gap by examining China's compliance with the Montreal Protocol. I analyze the behavior of government and industry in response to the Protocol, and the importance of market and political factors. Understanding China's compliance with the Protocol is significant because it may provide an insight into how it will respond to other global environmental problems. It may also shed light on which factors are likely to influence China's (and perhaps other developing countries') success in complying with international environmental agreements.

\section{Measurement of Compliance with the Protocol}

To define compliance with an international environmental agreement, I draw upon definitions developed by Mitchell, and Weiss and Jacobson. ${ }^{7}$ Mitchell's

4. Ozone Secretariat, available at http://www.unep.org/ozone/index.asp.

5. Halon is most commonly found in two forms: halon 1211, a liquid streaming agent found in hand-held extinguishers which gasifies under normal atmospheric conditions, and halon 1301, a gaseous flooding agent, which is found in built-in flood systems.

6. Available at the website of China's State Environmental Protection Administration, http:// www.sepa.gov.cn.

7. Mitchell 1994; and Weiss and Jacobson 1998. 
definition of requirements of an international environmental agreement focuses on specific treaty rules, while Weiss and Jacobson address both treaty rules and country rules that respond to the treaty rules. Compliance refers to whether countries adhere to the provisions of a treaty and to the implementing measures that they have adopted. ${ }^{8}$

The Montreal Protocol established the Multilateral Fund in 1991 to provide financial and technical assistance to Article 5 countries, which are defined as signatory developing countries that have an annual consumption of ODS lower than $0.3 \mathrm{~kg}$ per capita. The MLF stipulates requirements for countries to be eligible for assistance, including the formulation of a country program and a policy framework for the implementation of the Protocol. ${ }^{9}$ China's Country Program for the Phaseout of Ozone Depleting Substances under the Montreal Protocol (hereafter referred to as "China's Country Program" or the "Country Program") was issued in 1993 and revised in 1998. It presents China's plans and measures for completing its commitments under the Protocol. ${ }^{10}$ The initial Country Program set goals for the year 1996 since the Protocol did not require substantive ODS reduction until 1999. My compliance analysis focuses on three levels of rules: the Montreal Protocol, the requirements of the MLF, and the targets in the Country Program.

I examine two dimensions of compliance to these rules. Previous studies of compliance with international environmental treaties generally focus on the achievement of treaty goals; ${ }^{11}$ I refer to this as substantive compliance. Substantive requirements refer to the obligations to cease or limit an activity, such as the obligations of signatories to the Montreal Protocol to phase out consumption of ODS by a certain date. Most international environmental treaties also include procedural requirements; that is, obligations such as requirements for reporting data, establishing institutions, and so forth. ${ }^{12}$ Even though procedural compliance does not guarantee substantive compliance, it provides a legal and institutional framework for satisfying substantive requirements in a sustainable fashion.

Finally, my compliance analysis focuses on two types of actors-government and industry - that are primarily responsible for China's compliance with the Protocol. The state, which is the usual focus of studies of international relations, is not the sole actor affected by international environmental treaties. Industries, nongovernmental organizations, and individual citizens may all be involved in activities encompassed by international environmental treaties. With respect to implementation of the Montreal Protocol in China, industries are the main groups regulated by the Protocol; they are the parties that must eliminate ODS consumption and production, while the central government plays the key role in meeting procedural obligations.

8. Weiss and Jacobson 1998.

9. MLF Secretariat 2004.

10. SEPA 1993.

11. See, for example, Victor, Raustiala, and Skolnikoff 1998; and Jacobson and Weiss 1997.

12. Porter, Brown, and Chasek 2000, 148-157. 
This research is based on ten months of intensive field research in 1996 and 1997, and follow-up data collection from 1998 to 2004. The field research was conducted in Beijing, Shanghai, Hangzhou, Xinxiang, Qingdao, and Tianjin, and included structured interviews, reviews of documents, and direct observation. I interviewed international experts and officials from the World Bank, United Nations Environment Programme (UNEP), and US Environmental Protection Agency. I also draw upon secondary data from the UNEP, Ozone Secretariat, and China's government and research agencies. Multiple sources of data collection enabled me to double-check facts and arguments, enhancing data reliability. Even though there were problems of data quality initially, China's State Environmental Protection Administration (SEPA) and other agencies improved data quality steadily through fifteen years of hard work with individual factories and with the assistance of international agencies. ${ }^{13}$ The Protocol assisted China in building the administrative capacity to collect reliable data.

\section{China's Compliance with the Protocol}

\subsection{Procedural Compliance}

Under the Montreal Protocol (including the Multilateral Fund), the procedural obligations for Article 5 countries were to create an institutional framework, a country program, a policy framework, and a data reporting system. China's national government satisfied these four procedural requirements through four major actions. The first was creation of a national administrative system to coordinate existing ministries' work toward treaty compliance. The lead organization is the National Leading Group for Ozone Layer Protection, which is composed of 18 ministries and commissions and coordinated by SEPA. The Leading Group makes decisions on China's implementation of the Protocol, but the decision to ratify amendments requires approval from the State Council. A Project Management Office (PMO) was established within SEPA in 1991. The PMO Coordinates with other government agencies that are part of the Leading Group and is the agency responsible for implementing policies and programs approved by the Leading Group. The second action was completion of a Country Program that sets out China's plans to meet its obligations under the Protocol and the phaseout strategies for the main ODS production and consumption sectors. The Country Program was updated in 1998 based on 1997 ODS consumption and production data. The third government action was the formula-

13. It is possible to provide false data for a short time but it is not easy to do so for a long time under the requirements of the Montreal Protocol. Based on my interviews with Chinese and UNEP officials, China has an incentive to provide accurate (or close to accurate) data because if China over-reports ODS levels, they would fail to show progress in ODS reduction, but if they underreport ODS levels, they would not qualify for sufficient MLF funds. In addition, except for solvent and foam sectors, there are limited numbers of firms in ODS sectors, which makes them relatively easy to monitor. 
tion of national policies and regulations to limit ODS consumption and production in industrial enterprises. Finally, the government provided data on the production, export, and import of ODS from 1991 to 2001 to the Ozone Secretariat and the MLF Secretariat. ${ }^{14}$

Chinese national agencies improved their performance and procedural compliance over time through "learning by doing" and capacity building supported by training, financial support, and technical assistance from the MLF. Major changes in implementation strategies included greater involvement of local governments (especially environmental protection bureaus, or EPBs) in China's administrative system for Protocol implementation and data collection. Further, the government introduced a mix of market-based instruments and command and control policies with ODS reduction policies integrated into broader environmental policies. Even though the improved strategies are still not problem-free, they are much more effective than initial strategies to facilitate ODS reduction. These changes will be discussed in greater detail below.

\subsection{Substantive Compliance}

I evaluate China's compliance with the Protocol's substantive requirements by comparing the country's ODS reduction with the goals specified in both its own Country Program and the Protocol. As stated above, China's 1993 Country Program set its own short-term goal-to reduce ODS consumption and production levels in 1996 to be less than or equal to 1991 levels. Under the Protocol, Article 5 countries (including China) are required to freeze consumption and production of CFCs and halons at average 1995-1997 levels by 1999 and 2002, respectively (see Table 1). Subsequently, they are expected to reduce CFCs, halons, and CTC by 50 percent by 2005 and 85 percent by 2007, and to fully phase them out by 2010. Methyl bromide must be reduced by 20 percent by 2005, and phased out by 2015 .

\subsubsection{Current Compliance Status}

China met the 1999 freeze targets set in the Protocol and is also moving towards reaching the 50 percent reduction goals for 2005. However, it did not meet its own 1996 goals as specified in its Country Program. Overall ODS production and consumption levels in 1996 exceeded targets by 94 and 65 percent, respectively. From 1998 on, China's progress in ODS reduction accelerated and major ODS-CFCs, halons, and CTC-were greatly reduced by 2002 (see Figure 1). China met the Protocol's goals to freeze the production and consumption of major halons and CFCs by 1998 and 1999, respectively. By 1998, halon consumption and production levels were already 35 and 32 percent lower than the average 1995-97 levels, four years ahead of the Protocol's freeze targets for 2002; and by 2002, halon production and consumption had been reduced by

14. The Ozone Secretariat defines ODS consumption to be equal to production plus imports minus exports (Ozone Secretariat 2002). 
Table 1

Montreal Protocol Controlled Substances Phaseout Schedule for Article 5 Countries (reduction percentage compared to base level)

\begin{tabular}{|c|c|c|c|c|c|c|c|c|}
\hline Control Substances & 1996 & 1999 & 2002 & 2003 & 2005 & $\begin{array}{c}200 \\
7\end{array}$ & $\begin{array}{c}201 \\
0\end{array}$ & $\begin{array}{c}201 \\
5\end{array}$ \\
\hline CFCs & & freeze & & & 50 & 85 & 100 & \\
\hline Halons & & & freeze & & 50 & & 100 & \\
\hline Other CFCs & & & & 20 & & 85 & 100 & \\
\hline CTC & & & & & 85 & & 100 & \\
\hline $\begin{array}{l}\text { Methyl Chloroform } \\
\text { HCFCs }\end{array}$ & & & & freeze & 30 & & 70 & $\begin{array}{l}100 \\
\text { base }\end{array}$ \\
\hline Bromochloromethane & & & 100 & & & & & \\
\hline Methyl Bromide & & & freeze & & 20 & & & 100 \\
\hline
\end{tabular}

Source: Ozone Secretariat: http://www.unep.org/ozone.

Notes: 1. Base level for CFCs and halons are average of 1995-97; base level for other CFCs, CTC, methyl chloroform are the average of 1998-2000; Base level for methyl bromide is the average of 1995-98.

2. HCFCs are required to be frozen in 2016 at the levels in 2015.

84 percent, three years ahead of 50 percent reduction targets for 2005. Actual CFC consumption and production levels in 1999 were about 26 percent and 5 percent below the Protocol targets. China phased out CFC consumption in the aerosol sector by 1993 (except for essential use) as well as the use of CFCs in air conditioning for newly manufactured cars in 2001. As for CTC, by 2002 production and consumption had been reduced by 89 percent and 94 percent, respectively, 3 years ahead of the 85 percent reduction targets set by the Protocol. It also met the freeze target for methyl bromide. In 2002, production and consumption of methyl bromide were 4 and 1 percent lower than the targeted average levels from 1995 to 1998.

In total, by the end of July 2003, China phased out more than 53,932 ozone depletion potential (ODP) tonnes of production and 87,584 tonnes of consumption. ${ }^{15}$ Figure 2 shows changes in CFC consumption and production over time (compared to unconstrained CFC demand). The World Bank reported that China's work to decrease emissions of ODS over the past 12 years accounted for half of the total ODS emissions decrease worldwide. ${ }^{16}$ In March 2003, the World Bank presented Environment Minister Xie Zhenhua with the World Bank's annual Green Award for his outstanding leadership in protecting the ozone layer, and in September 2003, China was recognized by the Ozone Secretariat as an outstanding National Ozone Unit because of the country's progress in meeting compliance targets. ${ }^{17}$

15. Ozone Action in China, 30 October, 2003.

16. The World Bank and the Montreal Protocol, available at http://www.worldbank.org/.

17. China Daily, 15 March and 22 April, 2003. 
Figure 1

China's Fulfillment of Montreal Protocol Targets

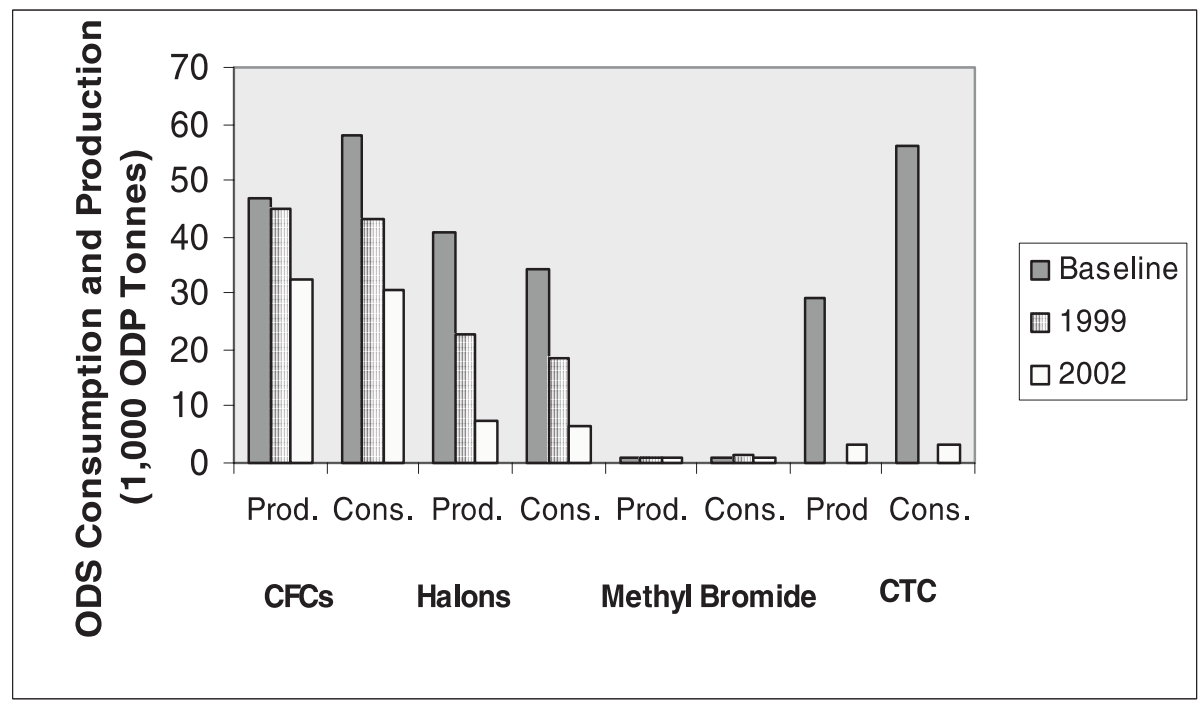

Sources: Data obtained from the Ozone Secretariat, 2003; PMO 2003; and World Bank, 2004.

Notes: 1. Baselines for CFCs and halons are the averages of production or consumption from 1995 to 1997 period. The baseline for methyl bromide is the average from 1995 to 1998. The baseline for CTC is the average from 1998 to 2000.

2. ODP, ozone depletion potential, refers to a numerical estimate of the total quality of ozone destroyed by a chemical substance over its entire atmospheric life relative to CFC 11.

\subsubsection{Potential and Challenges in Meeting the Protocol's Final Reduction Targets}

China is on track to comply with the Protocol's target to phase out CFCs and halons by 2010. Much of its current success is attributable to the use of the sector approach to financing, which targets national level ODS reduction in a particular sector with annual phaseout targets. ${ }^{18}$ These targets are met through a combination of policy measures and economic incentives. With continuous efforts under the sector approach, production and consumption of halons and CFCs will continue to decrease. There were only two halon producers and 20 halon consumers left in China in 2003. The country plans to completely phase out halon 1211 by January 2006, far ahead of the 2010 deadline required by the Protocol. After 2005, production and consumption of halon 1301 will remain at 150 tonnes and 100 tonnes respectively and will be eliminated completely by December 2009. It is highly likely that China will meet the 50 percent reduction

18. The details on the sector approach is discussed below. 
Figure 2

CFC Production and Consumption between 1986 and 2002

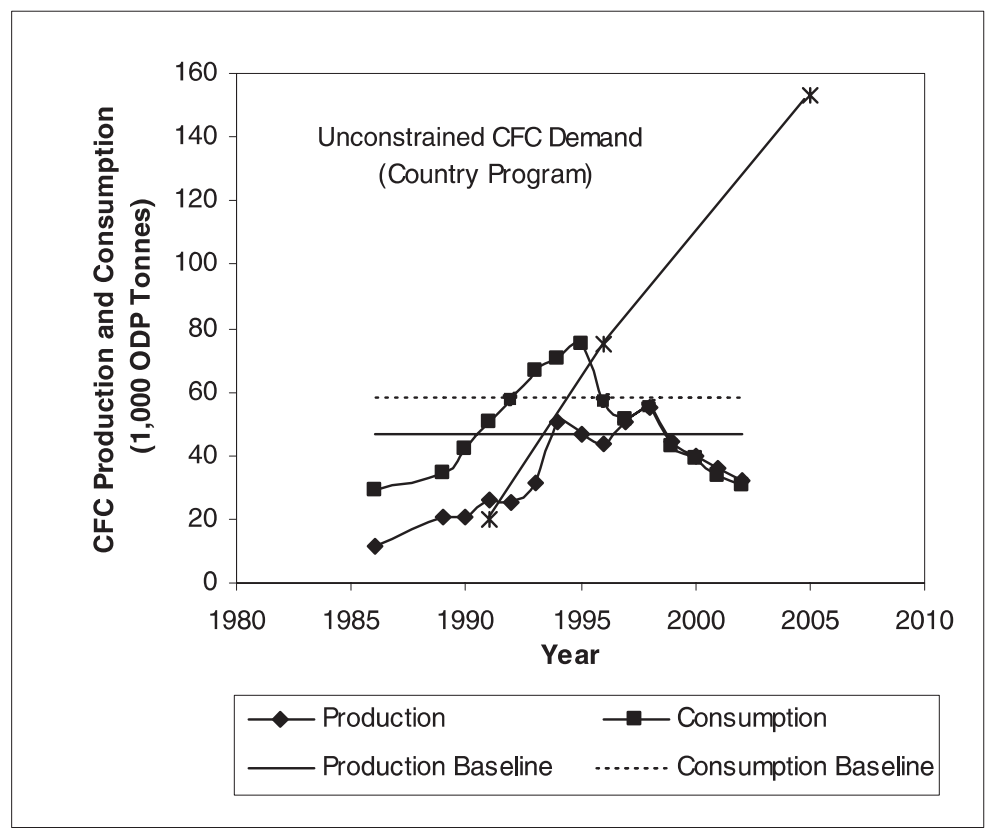

Source: Data obtained from the Ozone Secretariat 2003; and CES 1998b.

target for CFCs in 2005, and the complete phaseout target in 2010. By January 2003, CFC production in China had been reduced by 40 percent and 32 production plants had been closed and dismantled. ${ }^{19}$ In order to meet the 50 percent reduction target, China only needs to reduce annual CFC production by an additional 10 percent within 2 years. The country plans to completely stop the production of CFCs by the end of 2008 by shutting down the five remaining CFC-producing enterprises. ${ }^{20}$ China is currently applying the sector approach for $\mathrm{CFC}$ consumption sectors such as refrigerators, tobacco, and foams and is reducing CFC consumption in accordance with annual phaseout targets.

However, there are still challenges for China's successful compliance with the Protocol. ${ }^{21}$ One challenge is the high price and low availability of substitutes. Some substitutes cannot be produced domestically because of lack of technology. Even when they can be produced domestically, the cost is often high due to the small scale of production. These problems create an incentive

19. World Bank 2004, 29.

20. China Daily, 15 March 2003 and 4 October 2004.

21. Interviews with SEPA officials, a UNEP official, a professor at Peking University, July 2004, Beijing. 
for illegal production, consumption, and trade of ODS, in particular CFCs and halons. Another challenge is that the service sector for refrigerators and mobile air conditioning has little understanding of how to support CFC reduction goals and there are no policies to encourage the recycling of CFCs. It is necessary to recover, recycle, and reuse CFCs in order to reduce the demand for new CFC production.

\section{Analysis of China's Compliance}

Previous research has found that China ratified the Montreal Protocol for several reasons. One of the key reasons was that the Chinese government believed it was important to protect the ozone layer, and it wished to demonstrate that it could be a cooperative player in the international arena. It also aimed to keep abreast of changes in international technology, and to obtain resources made available through the Multilateral Fund. ${ }^{22}$ Given these motivations, why did China fail to meet its earlier reduction goals specified in the 1996 Country Program? And what has made it successful in its current compliance with the Protocol goals? Based on the field research described above, I examined the implementation process and interactions among those implementing the Protocol with the aim of determining the factors driving the behavior of both the government and industry. Table 2 lists these key factors, providing a dynamic view of how these factors changed over time. I divide the factors into three categories: (1) the design and operation of the MLF; (2) characteristics of government agencies and industries; and (3) China's opening to the outside world and its transition to a more market-oriented economy.

My research suggests that the change in China's substantive compliance over time was the result of changes in these factors influencing its compliance. Even though all factors interact with each other to produce a combined effect on compliance, the MLF was a particularly critical factor in China's compliance. The unique design of the MLF, which links access to its funds to satisfaction of procedural requirements, established the primary driving force behind the Chinese government's procedural compliance. A key factor in accelerating China's ODS reduction since the late 1990s was the adoption of a sector approach to MLF funding, which approved funds for sectoral ODS reduction strategies contingent on continuous evidence of progress, rather than approving each project individually. Changes in the availability and distribution of MLF money, features of technology transfer, the involvement of local governments, the capacity of government agencies and industries, and the adoption of specific policy instruments all contributed to China's ability to meet the Protocol requirements. In addition, both the government and industry are affected by the country's transition to a market-oriented economy.

22. Poppele 1994; Oksenberg and Economy 1998; and Zhao 2000. 
Table 2

A Dynamic View of Factors Affecting China's Substantive Compliance with the Protocol

\begin{tabular}{|c|c|c|c|}
\hline \multicolumn{2}{|c|}{ Factors } & $\begin{array}{l}\text { Problems contributing } \\
\text { to China's inability to } \\
\text { meet the Country Pro- } \\
\text { gram's } 1996 \text { targets }\end{array}$ & $\begin{array}{l}\text { Changes in factors con- } \\
\text { tributing to attainment } \\
\text { of Protocol targets be- } \\
\text { tween } 1999 \text { and } 2003\end{array}$ \\
\hline \multirow[t]{3}{*}{$\begin{array}{l}\text { Design and } \\
\text { operation of MLF }\end{array}$} & $\begin{array}{l}\text { Sector approach to } \\
\text { funding }\end{array}$ & $\begin{array}{l}\text { Project-by-project } \\
\text { approach }\end{array}$ & $\begin{array}{l}\text { Umbrella and sector } \\
\text { approaches }\end{array}$ \\
\hline & $\begin{array}{l}\text { Availability and dis- } \\
\text { tribution of MLF } \\
\text { money }\end{array}$ & $\begin{array}{l}\text { MLF fund shortages and } \\
\text { ineffective distribution } \\
\text { of funds among sectors }\end{array}$ & $\begin{array}{l}\text { More funds available } \\
\text { and more effective dis- } \\
\text { tribution }\end{array}$ \\
\hline & Technology transfer & $\begin{array}{l}\text { Difficulties in technol- } \\
\text { ogy transfer }\end{array}$ & $\begin{array}{l}\text { Production of CFCs and } \\
\text { halons are supported }\end{array}$ \\
\hline \multirow{3}{*}{$\begin{array}{l}\text { Characteristics of } \\
\text { government agencies } \\
\text { and industries }\end{array}$} & $\begin{array}{l}\text { Involvement of local } \\
\text { government }\end{array}$ & $\begin{array}{l}\text { Exclusion of local gov- } \\
\text { ernments }\end{array}$ & $\begin{array}{l}\text { Inclusion of local gov- } \\
\text { ernments (e.g., EPBs) }\end{array}$ \\
\hline & $\begin{array}{l}\text { Capacity of govern- } \\
\text { ment agencies }\end{array}$ & $\begin{array}{l}\text { Inexperience and } \\
\text { relatively low adminis- } \\
\text { trative capacity }\end{array}$ & $\begin{array}{l}\text { Increased capacity in } \\
\text { implementing the Pro- } \\
\text { tocol through MLF assis- } \\
\text { tance and learning by } \\
\text { doing }\end{array}$ \\
\hline & Sector traits & $\begin{array}{l}\text { Low financial and } \\
\text { technical capability in } \\
\text { foam, CFC production, } \\
\text { and halon sectors }\end{array}$ & $\begin{array}{l}\text { Increased capability in } \\
\text { foam, CFC production } \\
\text { and halon sectors due } \\
\text { to assistance from the } \\
\text { MLF }\end{array}$ \\
\hline \multirow[t]{2}{*}{$\begin{array}{l}\text { Transitional } \\
\text { economy }\end{array}$} & $\begin{array}{l}\text { Opening to the } \\
\text { world and market } \\
\text { oriented economy }\end{array}$ & $\begin{array}{l}\text { Higher than expected } \\
\text { economic growth and } \\
\text { market demand for } \\
\text { ODS }\end{array}$ & $\begin{array}{l}\text { Relatively low economic } \\
\text { growth and increased } \\
\text { market demand for } \\
\text { non-ODS products }\end{array}$ \\
\hline & Policy instruments & $\begin{array}{l}\text { Heavy reliance on } \\
\text { command-and-control } \\
\text { policies with little atten- } \\
\text { tion to enforcement }\end{array}$ & $\begin{array}{l}\text { Increased emphasis on } \\
\text { market-based instru- } \\
\text { ments }\end{array}$ \\
\hline
\end{tabular}

\subsection{Design and Operation of MLF}

\subsubsection{The Sector Approach to MLF Funding}

The most critical determinant of China's progress in reducing ODS is the shift of the MLF funding mechanism from a project-by-project approach to a sector approach beginning in 1997. This goes a long way in explaining the turnaround in China's compliance with the Protocol's goals for CFCs and halons. Instead of funding individual projects, whereby each project was required to go through 
an application and approval procedure to obtain MLF funds, the sector approach allows the MLF Executive Committee to approve a phaseout plan for an entire sector, including the total incremental cost needed for the sector phaseout package. The sector approach overcame the shortcomings of the complicated and costly approval and funding procedures for individual projects, which is particularly important for a country such as China with a large number of ODS producers and consumers. In addition, the cost-effectiveness principle used by the MLF favored projects submitted by large enterprises and ignored small- and medium-sized enterprises. ${ }^{23}$ Even though each small enterprise produces or uses only small amounts of ODS, together the amounts were significant, and ignoring them seriously constrained efforts to achieve ODS reduction goals in China.

The sector approach eliminated important loopholes associated with the individual project funding that allowed projects to receive MLF funds even while aggregate ODS production and consumption increased. This increase occurred because ODS consumption and production easily shifted from enterprises with MLF projects to other enterprises, and the political and economic interests of managers, local governments, and industrial ministries strongly favored rapid industrial growth. ${ }^{24}$ This is one of reasons why China's total ODS consumption and production in the early 1990s continued to increase even though some enterprises had conducted ODS phase-out activities.

Failure of the project-by-project approach in reducing ODS led to conflicts between the Chinese government and the Protocol's Executive Committee over responsibility and access to funding. For example, in 1994 the MLF Executive Committee refused to pay for the closure of a workshop of Tongxiang Chemical Factory producing halon 1211 as had been agreed upon, even though this halon workshop had achieved a permanent 1,200-ton reduction. This refusal was due to the fact that China's total halon production continued to increase. ${ }^{25}$ The Chinese government argued that the increase in ODS was allowed as long as annual ODS consumption and production was lower than $0.3 \mathrm{~kg}$ per capita, while the MLF Executive Committee wanted to see an overall reduction. ${ }^{26}$ The Tongxiang project controversy led to discussions on reforming the MLF funding mechanism. The sector approach links fund eligibility and ODS-phaseouts through a performance-based disbursement system. Even though the funds for the sector phaseout program are agreed upon up-front, the Executive Committee releases

23. MLF Secretariat 2004.

24. Interviews with EPB officials and enterprise managers, July 1997, Hongzhou and Shanghai.

25. Author's interview with a PMO official, June 1997, Beijing; author's interview with the director of the closed workshop, who was responsible for the project and was thus under great pressure from his workers and the manager of the factory, 25 July 1997, Zhejiang.

26. Author's interviews with a PMO official, SEPA, 5 December 1999; author's interview with professors at Peking University, April and August 1997. Executive Committee of the MLF, 1995. Report of the Eighteenth Meeting of the Executive Committee of the Multilateral Fund for the Implementation of the Montreal Protocol. UNEP/Ozl.Pro/ExCom/18/75, Page 8. 
the funds annually based on evidence that ODS phaseout targets in the sector plan have been achieved.

The sector approach requires strong national government involvement and commitment of a national government to meeting annual targets for ODS phaseout. It assures the government a continuous stream of funds (provided that obligations are met) and allows it to develop a comprehensive approach to ODS phaseout based on the total funding provided. Chinese government has used a combination of comprehensive policy measures with financial incentives to help all enterprises in a given sector convert to substitutes. ${ }^{27}$

The sector approach has proven to be an effective means of facilitating ODS reduction in China. The country began using the sector approach to implement its halon sector reduction plan in late 1997 and its CFC production plan in $1999 .{ }^{28}$ The halon sector plan received US $\$ 62$ million, with an expected reduction of 41,000 ODP tons of production and 35,000 ODP tons of consumption, and the CFC production plan was granted US $\$ 150$ million to close 36 CFC producing facilities. ${ }^{29}$ National halon and CFC production quota systems, regulations and enforcement, and financial incentives such as a national auction and bidding system have helped ensure compliance with reduction goals. ${ }^{30} \mathrm{~A}$ net reduction of 6,000 tonnes of halon 1211 and 5,000 tonnes of CFCs by 1999 enabled China to meet the Protocol's goal to freeze production and consumption of CFCs and halons (see Figure 3) ${ }^{31}$ Based on World Bank estimates, this significant accomplishment in the halon sector was achieved for less than US $\$ 1.00 / \mathrm{kg}$ of ODP phased out-a savings of between 25 and 30 percent when compared to implementing halon projects individually in China. ${ }^{32}$ The sector approach has been employed for 7 more sectors in China, including the solvent, foam, mobile air conditioning, tobacco, and CTC production and process agent sectors, and in other countries, such as the refrigeration sector in both India and Turkey.

\subsubsection{Availability and Distribution of MLF Money}

The availability of MLF funds directly influenced China's ODS reduction activities. The receipt of less MLF funding than expected is one reason why it did not meet its reduction goals in its 1996 Country Program. By the end of 1996, China had received only US $\$ 126$ million from the MLF, or 28 percent of the funding it felt it needed to reach the voluntary reduction goal set in the Country

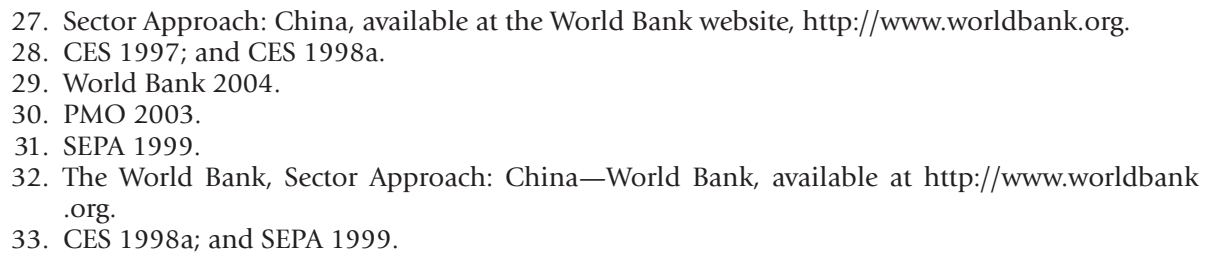


Figure 3

Effects of the Sector Approach on CFC and Halon Reduction

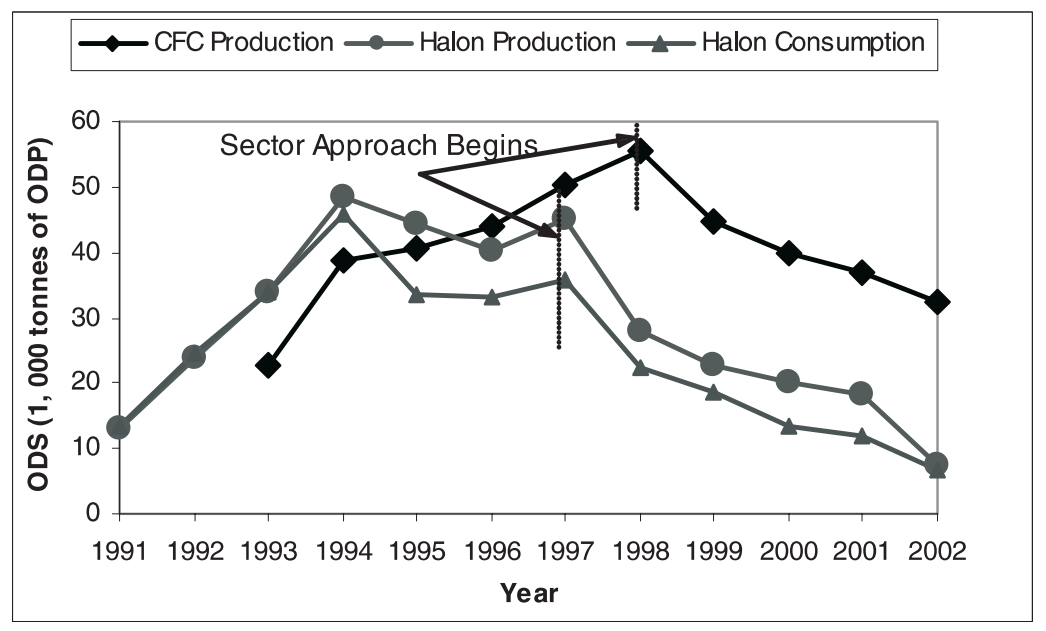

Sources: Data obtained from the Ozone Secretariat 2003.

Program. ${ }^{33}$ Another reason China failed to meet its own targets was that they were overly ambitious, which was partly the result of the eagerness of Chinese officials to obtain as much MLF funding as possible and their failure to anticipate the demands of its rapid economic GDP growth, which averaged 12 percent per annum during the early 1990s. ${ }^{34}$ In addition, before 1997, MLF funds did not go to sectors with the greatest need for support, such as the CFC production sector. Instead, enterprises in the household refrigeration sector received 32.7 percent of the MLF funds distributed in China up to 1996, even though firms in this sector would probably have shifted to non-CFC technologies on their own in response to domestic competition as well as the demands of international trading partners. ${ }^{35}$ This inefficient allocation of resources can be attributed to the MLF's inability to effectively utilize local markets and the lack of sector knowledge.

This situation changed in the late 1990s with increased funds combined with a focus on a sector approach. As of July 2003, China had received US $\$ 470$ million in MLF through 403 different projects including 9 sector plans. The total funding approved for China by the MLF is $\$ 740$ million, including funds approved over multiple years under the sector approach that will be released to China by $2010 .{ }^{36}$

34. Interview with Prof. Tang Xiaoyang, who is an expert on the drafting of China's Country Program at Peking University, 14 April 1997, Beijing. Also based on interviews with over 10 officials from SEPA and other ministries.

35. CES 1998b. Interviews with firm managers, June 1997, Qingdao and Xinxiang.

36. China Daily, 9 March 2004. 


\subsubsection{Problems with Technology Transfer}

The Protocol requires that the best available and environmentally safe technologies are expeditiously transferred to Article 5 countries under the most favorable and fair conditions. However, China has encountered barriers in technology transfer that have slowed ODS reduction. The nature of the barriers varies sector by sector, depending on the complexity of the required technologies. The most difficult issue that China has faced is the transfer of technology for producing ODS substitutes. Even though the MLF Executive Committee finally approved the sector plan for the closure of CFC production facilities in China in 1999, it could not reach agreement on support for the production of CFC substitutes. ${ }^{37}$ Industries in developed countries that created and profited from ODS substitutes were reluctant to relinquish their control over manufacturing these chemicals, and they were concerned about the protection of intellectual property rights. ${ }^{38}$ China's poor record on intellectual property rights protection and the lack of a better enforcement system also contributed to the unwillingness of foreign firms to transfer technology to China. ${ }^{39}$

SEPA officials attributed the low level of domestically produced ODS substitutes to the failure of the MLF to support the development of substitute technology and products. ${ }^{40}$ The heavy reliance on imported substitutes was a barrier to rapid ODS reduction for some sectors and a challenge to China's complete phasing out of ODS. After negotiation with the Chinese government, the MLF Executive Committee finally allowed the country to use some of the funds that support the closure of CFC production facilities to build production facilities producing CFC substitutes. This flexibility in the use of funds has resulted in the establishment in 2002 of the Environmental Protection Industrial Park for Compliance with International Agreements in Langfang City, Hebei Province, to serve as a home for enterprises developing and producing substitutes for ODS. ${ }^{41}$ China is currently researching substitutes for materials used in tobacco production, refrigerators, aerosol propellants and fire extinguishers.

Firms like to transfer equipment rather than technological "know-how," particularly that tied to the production process. ${ }^{42}$ In China's energy sector, Evans observed an emphasis on transfer of capital goods and equipment rather than on operations, maintenance, and manufacturing technologies. ${ }^{43}$ He found that firms owning technologies have limited interest in sharing design or production know-how, or other capabilities that would increase a developing country's ability to manufacture new technologies locally.

37. CES 1998a.

38. Author's interview with US Environmental Protection Agency officials, Washington DC, August 1998; author's interview with a professor at Peking University, Beijing, July 1999.

39. Interview with a UNEP official, July 2004, Beijing.

40. China Daily, 16 June 2002.

41. Ozone Action in China, 30 July 2002

42. See, for example, Evans 1999; and Watson 1999.

43. Evans 1999 
Some enterprises that received financial support to change their technologies encountered problems during the technology transfer process. One problem was finding appropriate suppliers of ODS-reduction technologies. In some cases, only one or two owners of such technologies were willing to provide them, and these owners generally were small in size. Small technology suppliers had weak technical abilities and could not provide enterprises with complete technology information and technical assistance, slowing down project implementation. ${ }^{44}$ Some large companies in Article 2 countries either exhibited little interest in participating-perhaps because they would rather sell products than transfer technology, or no longer even employed technologies that could have been transferred to China. Because the MLF does not support technology upgrades, technologies that are transferable to China are not always the most advanced.

The excessive requirements imposed by ODS-reduction technology suppliers in industrialized countries, such as establishing a joint-venture or receipt of some of the profits from using the new technology, was another problem faced by China. These demands caused delays because much more time was spent in negotiating agreements. In addition, the capability of recipient enterprises affects the technology transfer process. Some enterprises faced problems when they did not have sufficient knowledge about new equipment or technology. ${ }^{45}$ The PMO's Director believed that training workshops and the information network associated with MLF projects advanced enterprises' knowledge and capability, becoming an integral part of any technology transfer process. ${ }^{46}$

\subsection{Characteristics of Government Agencies and Industries}

\subsubsection{Government Motivation and Capacity}

The unique design of the MLF, which links access to funds to the satisfaction of procedural requirements, established the primary driving force for the Chinese government's procedural compliance and continuous improvement of its implementation strategies. ${ }^{47}$ China's desire to demonstrate to the world that it was a cooperative and responsible international actor was another incentive for the government's efforts toward procedural compliance. ${ }^{48}$ Part of its need to demonstrate its cooperative position arose from international pressure and concerns about China's impact on the global environment. ${ }^{49}$

44. Author's interviews with managers of aerosol filling factories, 12 July 1997, Hangzhou, and 5 August 1997, Shanghai.

45. Interviews with firm managers, June-July 1997, Shanghai, Hongzhou, Beijing, and Tianjin.

46. United Nations Environment Programme, OzoneAction, No. 28, October 1998.

47. Zhao 2000.

48. Oksenberg and Economy 1999, 5.

49. Ozone Action in China, No. 4, September 1995. 
The Protocol gave China a good opportunity to demonstrate its commitment to solving international environmental problems. ${ }^{50}$ Its compliance with the Protocol involved low costs and modest impacts on its economy. Moreover, financial and technical assistance provided by the MLF reduced the difficulty and costs of compliance. In November 1999, China voluntarily hosted the Eleventh Meeting of the Parties to the Montreal Protocol and the Fifth Meeting of the Parties to the Vienna Convention, which cost the country about US $\$ 2.2$ million. ${ }^{51}$ China's efforts to be a responsible and cooperative international actor were recognized by Richard Benedick, a principal architect and the chief US negotiator of the Protocol. He wrote "China has also been from the beginning one of the most cooperative and conscientious parties to the Montreal Protocol, notwithstanding the needs of its large and rapidly expanding economy." 52

Domestically, it was in the interests of SEPA and the Project Management Office to comply with the Protocol. Implementation of the Protocol gave SEPA the opportunity to demonstrate its capability to manage global environmental issues and gain increased control over China's other efforts to solve international environmental problems. ${ }^{53}$ For example, after the 1998 government restructuring SEPA obtained new authority to negotiate and coordinate IEAs, such as the Convention on Biological Diversity and the Climate Change Convention. ${ }^{54}$ The MLF also created additional opportunities for the PMO, including access to new office equipment, power to allocate MLF funds among industrial sectors, possibilities for travel by PMO staff, and opportunities for staff training. In order to maintain these interests, the PMO worked hard to secure its position and monopoly control over implementing the Protocol in China. ${ }^{55}$

Enhanced administrative capacity obtained through training and technical assistance from the MLF also played an important role in China's compliance. This administrative capacity includes the management, knowledge, and information used by government agencies to design and implement policies. The Chinese government's efforts to implement the Protocol during the early 1990s were impeded by administrative deficiencies such as insufficient resources and lack of experience. Officials and experts believe this contributed to China's failure to meet the 1996 target set in its Country Program. ${ }^{56}$ According to the

50. Interviews with officials at the PMO, Director of Air Pollution Control at SEPA, Deputy Administrator of NEPA, and an official in the State Development and Planning Committee, 22 August and 16 September 1997.

51. Interview with the PMO Director, 1 December 1999, Beijing.

52. Benedick 1998, 264.

53. Interviews with SEPA officials, July 1997 and December 1999; interview with an official in the former State Planning Commission, August 1997, Beijing. Interviews with officials in the State Planning Commission and in the Ministry of Chemical Industry, 6 and 15 April 1997, Beijing.

54. Environomics ERM China, "The State Environmental Protection Administration: A New Environment in Government?", ERM China, August 1998.

55. Interviews with SEPA officials, August 1997 and June 2001, Beijing.

56. Interview with SEPA officials, August 1997; Interview with UNEP official and professors at Peking University, October 2003, Beijing. 
PMO's Director, training of officials in central government agencies, local environmental protection bureaus, and customs offices have all been essential in improving China's implementation of the Protocol. ${ }^{57}$ Obtaining training and technical assistance from the MLF contributed to capacity building, which was further shaped by experience or "learning by doing."

\subsubsection{Involvement of Local Governments}

Another major action taken by SEPA was to increase the involvement of local government agencies in project implementation. Before 1997, China's administrative system for implementation of the Protocol excluded local environmental protection bureaus and industrial bureaus even though generally local EPBs enforce regulations issued by SEPA. Without their involvement, regulations on ODS reduction were not well enforced, and SEPA had difficulty obtaining quality data and verifying the data submitted by industrial ministries. ${ }^{58}$ In addition, SEPA and relevant industrial ministries did not have enough staff to adequately supervise the implementation of MLF projects throughout China. SEPA argued that EPBs were not included in ODS-reduction work to simplify management procedures, but some local governments believed SEPA excluded them in order to control the resources it received from the MLF. ${ }^{59}$

In 1997, SEPA organized a review of ODS reduction activities as preparation for the revision of China's Country Program and recognized the problems caused by excluding EPBs from Protocol implementation. In February 1997, SEPA issued a circular requiring EPBs to monitor the phaseout of CFCs. ${ }^{60}$ The 1998 Update of China's Country Program further clarified responsibilities of local EPBs in policy implementation, monitoring, data collection, and project management. ${ }^{61}$ The involvement of local governments has improved the management of ODS reduction activities. But enforcement is still not very strict, and insufficient financial and technical training for EPBs still pose problems for project monitoring.

The importance of local government participation in environmental policy implementation is also noted in other countries. For example, Eckerberg concludes that policy implementation was crucially dependent on active support at the local level in Sweden. ${ }^{62}$ She finds that "two-way communication"

57. United Nations Environment Programme, OzoneAction, No. 28, October 1998.

58. In the early 1990s, industrial ministries had incentives to overstate ODS consumption in order to be eligible for more MLF money and they were not familiar with the status of ODS production and consumption due to decentralization. Interviews with officials in the PMO, the Plastic Industry Office, and China Household Electrical Appliance Association, 9 May and 15 May 1997, Beijing.

59. Author's interview with EPB officials, Hangzhou, 18 July 1997; Shanghai, 8 August 1997, and 13 August 1997, Beijing.

60. SEPA 1997. Circular on Strengthening the Monitoring and Supervision Function for Ozone Layer Protection by Local EPBs (Jiaqiang difang huanbaoju zai chouyangceng baohu zhong de jiandu zhineng).

61. SEPA 1998.

62. Eckerberg 1997. 
throughout the formulation and implementation of environmental or development policy, from the local to the national level-and vice versa-may help in the design of effective strategies to cope with environmental issues.

\subsubsection{Sector Characteristics and Industrial Responses}

The success of enterprises in reducing ODS varied more by sector than by location. The aerosol sector completely phased out CFCs (except for essential medical use) by the end of 1997, far in advance of the Protocol's required 2010 deadline, and enterprises in the household refrigeration sector began to conduct ODS-reduction activities even before China ratified the Montreal Protocol. In contrast, enterprises in the foam and solvent sectors were slow in reducing ODS.

The varying performance of industrial sectors resulted from differences in the number and size of enterprises, forms of ownership, complexity of technologies, and financial and technical capabilities. The household refrigeration sector has a small number of large enterprises; and a notable fraction of them employ imported technologies. ${ }^{63}$ Due to their strong financial and technical capabilities, refrigerator manufacturers were able to either switch to reducedCFC or non-CFC technologies on their own, or satisfy MLF funding criteria and receive MLF grants.

In contrast, the foam sector had a large number of small-sized producers, many of which were rural enterprises scattered throughout the countryside. These enterprises lacked the technical skills, financial resources, and access to information necessary to adopt new technologies and compete for MLF funds. Initially the MLF focused on large ODS consumers and producers due to their high cost-effectiveness in terms of ODS reduction. Some of these impediments to ODS reduction were reduced in 1997, when China began to use an "umbrella approach," which brought together numerous small enterprises to apply for MLF money. This approach saves time by avoiding repeated processing for individual, smaller grant projects, but also allows those ineligible for MLF funds to receive financial support. Under the umbrella and sector approaches, the PMO facilitated the merger of small firms and helped firms to produce products that did not use ODS. Restructuring helped increase the scale of enterprises and their competitiveness. For example, with the support of MLF, four small solvent firms merged and established a united environmental equipment corporation. ${ }^{64}$

The varying performance of industrial sectors also resulted from intersectoral differences in the costs of changing from technologies that use (or produce) ODS to those that use (or produce) ODS substitutes. Opportunities to cut production costs by using CFC substitutes played a key role in CFC reduction for the aerosol sector. In contrast, for the CFC production and halon sectors, the high cost (e.g., capital requirements and unemployment of workers) associated

63. Zhao and Ortolano 1999.

64. Ozone Action in China, March 2004. Interviews with PMO officials, July 2004, Beijing. 
with technological change made enterprises highly dependent upon financial and technical assistance from the MLF.

\subsection{China's Opening to the World and Transition to a Market Economy}

With the transition to a market economy, market demand has become a major factor influencing the behaviour of enterprises. ${ }^{65}$ China now has a welldeveloped market system for allocating nearly all goods and services in the economy. As a result, market-based instruments supported by national regulations have proven more effective than sole reliance on command and control policies in encouraging enterprises to move to non-ODS technologies. The effectiveness of command-and-control policies is limited by deficiencies in enforcement and implementation of regulations.

Differences in market demand caused enterprises in different sectors to exhibit varied behaviors-either to move to non-ODS technologies or to maintain their existing production systems. ${ }^{66}$ Consumer preferences in European markets, for example, along with the requirements of international trading partners, motivated the initial move to reduced-CFC technologies in China's household refrigeration sector. These factors, plus the influence of multinational corporations that began manufacturing refrigerators in China, pushed the majority of Chinese refrigerator firms to cut their use of CFCs. In contrast, corresponding pressure for change did not exist in the foam, halon, and CFC production sectors. However, rapid domestic growth of industries using ODS, and increased legal (and illegal) exports of halon and CFC, generated a high demand for ODS, which encouraged enterprises to continue to produce CFCs and halons.

China's environmental labeling program is another trade-related mechanism that has contributed to the reduction of CFCs. At the urging of refrigerator manufacturers who hoped that an environmental label would allow them to satisfy labeling requirements imposed by European countries, China created an environmental labeling program in 1993. ${ }^{67}$ This not only spurred an increase in the country's exports of refrigerators, but also provided stimulus for enterprises to switch to producing non-CFC refrigerators for the domestic market.

A further market-based instrument is quota trading and bidding within the sector approach. In 1998, SEPA introduced production quotas for halon and CFC phaseout to ensure that reduction goals were met as part of the sector approach. ${ }^{68}$ It also used bidding mechanisms to efficiently distribute MLF funds to enterprises in the halon and CFC production sectors each year. Quotas were tradable; and enterprises with quotas could sell them to other CFC producers or to the government. Bidding took place annually and participation was voluntary. SEPA ranked the offer prices proposed by participating firms and selected enterprises with the lowest prices until all available MLF funds were allocated

65. Luo, Zhou, and Liu 2003.

66. Zhao and Ortolano 1999.

67. Zhao and Xia 1999.

68. CES 1997 and 1998a. 
for that year. Because bidding was competitive, enterprises had incentives to bid close to their true estimates of costs, and the bidding process yielded outcomes that involved relatively low total cost for meeting a particular reduction target. The national auction and bidding system, combined with regulations on halon uses and forced closures of CFC production facilities, employed under the sector approach, led to significant reductions in the consumption and production of halons and CFCs (see Figure 3). This quota and bidding approach also has been applied to CTC reduction since 2003 and the annual reduction target for 2003 was achieved. ${ }^{69}$

\section{Conclusions and Policy Implications}

This article has focused on China's domestic implementation of a single international environmental treaty-the Montreal Protocol. The Montreal Protocol owes its success to many factors, some of which are not necessarily replicable in implementing future international environmental treaties. These include the limited number of industries involved, the availability of substitutes for ODS, the lack of any coherent and sustained industrial or public opposition, the relative certainty of scientific research, and the relatively low compliance costs. ${ }^{70}$ Specific features of the Montreal Protocol, such as the strong leadership of UNEP and the flexible design of the treaty to allow for revision, all contributed to successful country implementation of the Protocol. These factors created a preexisting context for China's implementation and are not discussed in the article. The conclusions of this article also need to be tested in a broader context by studying compliance with the Montreal Protocol in other Article 5 countries (e.g., India) and Article 2 countries (e.g., Russia), and by studying China's compliance with other environmental treaties (e.g., the Biodiversity Convention).

Nonetheless, China's compliance with the Montreal Protocol may provide important insights into the design of international environmental treaties, financial assistance mechanisms, and China's own treaty implementation strategies. This article suggests that the Multilateral Fund played a key role in China's successful compliance with the Protocol. The Fund provided China with strong incentives to ratify the Protocol, and its funds enabled the country to create and implement strategies to meet the Protocol's requirements. The MLF provided assistance to enterprises that otherwise might not have been able to undertake the initial capital investments needed to convert to non-ODS technologies. In addition, the MLF provided key assistance that greatly enhanced the capacity of the Chinese government agencies to implement the Protocol. This includes the provision of information and training, support for developing administrative capacity, assistance in data collection and development of national phaseout strategies, and initiation of demonstration projects. Market forces also played a role in encouraging some Chinese enterprises to switch to non-ODS technology, but

69. Ozone Action in China, 30 March, 2004.

70. See, for example, Brack 1996; and Downie 1995. 
China's experience suggests that market forces cannot fully substitute for the incentives and benefits of the MLF. Capital shortage and low technological capability of most Chinese enterprises are constraints that limit rapid adoption of new technology. The MLF made it possible for technological change to occur in a more orderly fashion and faster than it would have been possible otherwise.

China's experience with the Montreal Protocol suggests that financial and technical assistance is an effective, and likely essential, mechanism for engaging the participation of China and other developing countries in international environmental treaties. ${ }^{71}$ The Montreal Protocol achieved global cooperation through "common but differentiated responsibilities" of industrialized and developing countries with respect to global environmental problems. Even though it appears unlikely that developed countries will follow the MLF model in other IEAs, international experience with the Montreal Protocol provides evidence that there are various ways to reduce implementation costs and those opportunities exist for equitable and fair cooperation.

The success of the MLF can be attributed to its flexibility to continually improve implementation mechanisms. The funding approach shifted from an initial individual approach to an umbrella approach, and a sector approach. A main finding of this paper is that the sector-based approach in China was far more effective than the project-by-project approach in changing government and industry behavior to meet ODS reduction goals, and was the key to the remarkable turnaround in the country's compliance with the Protocol's freeze goals for CFCs and halons in the late 1990s. The sector approach overcame the shortcomings of the individual project approach by tying eligibility for MLF assistance to aggregate sector ODS-reduction performance, and by taking advantage of the national government's capability to monitor and manage. The application of tradable quotas and bidding mechanisms further enhanced the effectiveness of MLF assistance by encouraging enterprises to select the most cost-effective ODS reduction activities. Moreover, the MLF could have been even more effective if it gave careful consideration to sector traits and allocated funds to the sectors in greatest need of financial assistance.

The sector approach may be especially appropriate for large countries like China and India, where one sector can include a very large number of enterprises and a project-by-project approach quickly becomes unmanageable. Also, China had a long history of strong government control under central planning. The government regulated industry through sectoral ministries, and despite the country's transition to a market oriented system, there is still relatively strong sectoral integration and coordination. These reasons help explain why the sector approach was successful in China, and provide rationale for using similar approaches to address other global environmental problems, such as climate change.

Transfer of technological know-how is more difficult than transfer of equipment. Concern about intellectual property rights was a barrier to the

71. Biermann 1997; and French 1997. 
transfer of technology for producing ODS substitutes. Also, some firms that created and profited from ODS substitutes were reluctant to relinquish their control over the manufacture of those chemicals. This concern is typical; for example, it also appears in the context of the transfer of clean coal technology. Many international environmental treaties, such as agreements regarding climate change, involve technology transfer issues. Establishing a complete and enforceable regulatory system to protect intellectual property rights in China would be an important first step to move the technology transfer process forward.

China's compliance with the Montreal Protocol may provide important insights into domestic strategies that the country can adopt to enhance its compliance with other international environmental agreements. China's experience with the Montreal Protocol suggests that there are three factors that can significantly influence the government's ability to implement an international environmental agreement. They are government motivation and administrative capacity, the involvement of local governments, and the use of market-based instruments. Selecting an implementing agency that has interests consistent with meeting the goals of an international environmental agreement is critical for effective implementation. The implementing agency must also be given the staff, budget, training and other support necessary to function effectively. Moreover, it is important to make technical assistance and capacity-building programs available at local levels. Programs to "train the trainers" can be used to extend training from officials in national government agencies to officials at local levels. A combination of stringent enforcement of regulations and the use of market mechanisms can be effective in influencing industrial behavior. China is entering the most challenging stage of phasing out ODS as the deadline for complying with the Protocol's complete phaseout target nears. To be successful in the future, China must continue learning from the lessons of recent experience, emphasizing the approaches that have proven to be effective.

\section{References}

Batabyal, Amitrajeet A. 1998. Developing Countries and International Environmental Agreements: The Case of Perfect Correlation. International Review of Economics and Finance 7 (1): 85-102.

Benedick, Richard Elliot. 1998. Ozone Diplomacy: New Directions in Safeguarding the Planet. Cambridge MA: Harvard University Press.

Biermann, Frank. 1997. Financing Environmental Policies in the South-Experiences from the Multilateral Ozone Fund. International Environmental Affairs 9 (3).

Blancard, O., P. Criqui, A. Kitous, and L. Viguier. 2003, Combining Efficiency with Equity: A Pragmatic Approach. In Providing Global Public Goods: Managing Globalization, edited by I. Kaul, P. Conceicao, K. Le Goulven and R.U. Mendoza. Oxford: Oxford University Press.

Brack, Duncan. 1996. International Trade and the Montreal Protocol. London: Earthscan Publications Ltd.

CES (Center for Environmental Sciences). 1997. Sector Plan for Halon Phaseout in China. Beijing: Beijing University. 
.1998a. Sector Plan for CFC Production Phaseout in China (closure part). Beijing: Beijing University.

1998b. Review of the Implementation of China's Country Program for ODS Phaseout (draft). Beijing: Beijing University.

Downie, David Leonard. 1995. Road Map or False Trails? Evaluating the 'Precedence' of the Ozone Regime as a Model and Strategy for Global Climate Change. International Environmental Affairs 7 (4).

Eckerberg, Katarina. 1997. National and Local Policy Implementation as a Participatory Process. In International Governance on Environmental Issues, edited by Mats Rolen, Helen Sjoberg and Uno Svedin. Dordrecht: Kluwer Academic Publishers.

Evans, Peter C. 1999. Japan's Green Aid Plan: The Limits of State-Led Technology Transfer. Asian Survey. 39 (6).

French, Hilary F. 1997. Learning from the Ozone Experience. In State of the World, edited by L. R. Brown, C. Flavin and H. French. New York: W.W. Norton \& Company.

Intergovernmental Panel on Climate Change (IPCC). 2002. Beyond Kyoto: Energy Dynamics and Climate Stabilisation. Paris: OECD/IEA.

Jacobson, Harold K., and Edith Brown Weiss. 1997. Compliance with International Environmental Accords: Achievements and Strategies. In International Governance on Environmental Issues, edited by Mats Rolen, Helen Sjoberg and Uno Svedin. Dordrecht: Kluwer Academic Publishers.

Keohane, R., P. Haas, and M. Levy. 1993. The Effectiveness of International Environmental Institutions. In Institutions for the Earth, edited by P. Haas, R. Keohane and M. Levy. Cambridge, MA: The MIT Press.

Luo, Xueming, Lianxi Zhou, and Sandra S. Liu. 2003. Entrepreneurial Firms in the Context of China's Transition Economy: An Integrative Framework and Empirical Examination. Journal of Business Research. Available at http://www.sciencedirect.com, accessed September 25, 2004.

Mitchell, Ronald B. 1994. Intentional Oil Pollution at Sea: Environmental Policy and Treaty Compliance. Cambridge, MA: The MIT Press.

MLF Secretariat. 2004. Multilateral Fund for the Implementation of the Montreal Protocol: Policies, Procedures, Guidelines and Criteria. Nairobi: UNEP.

Oksenberg, Michel, and Elizabeth Economy. 1998. China's Accession to and Implementation of International Environmental Accords 1978-1995. In Engaging Countries: Strengthening Compliance with International Environmental Accords, edited by E.B. Weiss and H.K. Jacobson. Cambridge, MA: The MIT Press.

1999. Introduction: China Joins the World. In China Joins the World: Progress and Prospects, edited by Elizabeth Economy and Michel Oksenberg. New York: Council on Foreign Relations.

Ozone Secretariat. 2002. Production and Consumption of Ozone Depleting Substances under the Montreal Protocol, 1986-2000. Nairobi: UNEP.

Poppele, Jessica. 1994. The CFC Challenge. The China Business Review 21 (40): 34-38.

Project Management Office (PMO). 2003. China Country Compliance Plan: For the implementation of the Montreal Protocol. Beijing: SEPA.

Porter, Gareth, Janet Welsh Brown, and Pamela S. Chasek. 2000. Global Environmental Politics, $3^{\text {rd }}$ edition. Boulder. CO: Westview Press.

SEPA (State Environmental Protection Administration). 1993. Zhongguo Xiaojian Chouyang Haosunwuzhi Guojia Fangan (Country Program for the Phaseout of ODS under the Montreal Protocol). Beijing: SEPA. 
1997. Circular on Strengthening the Monitoring and Supervision Function for Ozone Layer Protection by Local EPBs (Jiaqiang difang huanbaoju zai chouyangceng baohu zhong de jiandu zhineng).

1998. Update of China's Country Program for Ozone Depleting Substances Phaseout. Beijing: SEPA.

1999. China Country Report on Ozone Layer Protection. Beijing: SEPA.

Victor, David G., Kal Raustiala, and Eugene B. Skolnikoff, eds. 1998. The Implementation and Effectiveness of International Environmental Commitments: Theory and Practice. Cambridge, MA: The MIT Press.

Watson, Jim. 1999. The Transfer of Cleaner Technologies to China: Learning from Experience. Proceedings of Second International Symposium on Clean Coal Technology. Beijing: China Coal Industry Publishing House.

Weiss, Edith Brown, and Harold K. Jacobson. 1998. Engaging Countries: Strengthening Compliance with International Environmental Accords. Cambridge, MA: The MIT Press.

World Bank. 2004. Montreal Protocol, Successful Partnerships for Ozone Protection-the Case of China. Washington, DC: The World Bank.

Zhao, Jimin. 2000. Implementing the Montreal Protocol in China. Unpublished doctoral dissertation, Stanford: Stanford University.

Zhao, Jimin, and Leonard Ortolano. 1999. Implementing the Montreal Protocol in China: Use of Cleaner Technology in Two Industrial Sectors. Environmental Impact Assessment Review September/November.

Zhao, Jimin, and Qing Xia. 1999. Environmental Labeling Program in China. Environmental Impact Assessment Review September/November. 